\title{
3
}

\section{Getting to Know Paul Dibb: An Overview of an Extraordinary Career}

\section{Desmond Ball}

This chapter, which provides a brief overview of some of the major milestones in Paul Dibb's varied career interspersed with personal reminiscence, is intended to convey the extraordinary breadth of his achievements and contributions, and to better understand the character and personality that has provided the agency for these achievements.

My first recollections of Paul go back to the mid- to late 1970s, or around 40 years ago, when Paul was head of the National Assessments Staff (NAS), which was part of the Joint Intelligence Organisation (JIO) but serving the National Intelligence Committee (NIC) (and hence often called the NIC-NAS), and the forerunner to the Office of National Assessments (ONA). He became Deputy Director (Civilian) of the JIO in 1978. I first heard about him from three people who were important figures in the early stages of his career.

One was Harry Rigby, a professor at The Australian National University (ANU) and an internationally recognised scholar of the Soviet Union and especially the Communist Party of the Soviet Union (CPSU). Paul's work on the Soviet economy had impressed Rigby when Paul was a research fellow in the Department of Political Science in the Research 
School of Social Sciences (RSSS) and then the Department of Human Geography in the Research School of Pacific Studies (RSPacS) at ANU in 1968-70. Paul's first major book, Siberia and the Pacific: A Study in Economic Development and Trade Prospects, published in 1972. ${ }^{1}$

The second was Bruce Miller, the head of the Department of International Relations at ANU. He participated as a member of a small group of academics in regular weekly meetings with Paul and other NAS staff during the preparation of the foundational study The Environment of the 1980s, completed in 1971. This was an exercise in forecasting in such areas as the global strategic balance, nuclear proliferation, developments in military and non-military (including transportation and communications) technologies, world energy requirements, and regional economic and political developments. It delineated the framework from within which strategic documentation over the next decade was derived.

The third was Bob Mathams, then the Director of Scientific and Technical Intelligence in JIO and a good friend of the Centre, later serving through the 1980s on the Centre's Advisory Board. In 1966, Mathams became the principal interlocutor with the CIA regarding selection of Pine Gap for the construction of the ground control station for the CIA's innovative new geostationary signals intelligence (SIGINT) satellites, then code-named 'Rhyolite', which were designed to intercept, inter alia, the telemetry generated in Soviet ballistic missile and other advanced weapons tests. Matham replaced E.L.D. White, the head of the Defence Science Division in the Department of Defence, as head of the site selection team. This program gave Australia a central role in maintenance of the global strategic balance and, at a personal level, forged connections between Australian defence and intelligence officials and the hierarchy of the CIA's Deputy Director, Science and Technology (DDS\&T), the so-called 'wizards of Langley' — men such as Albert 'Bud' Wheelon, Carl Duckett and Leslie C. Dirks. ${ }^{2}$

I really got to know Paul in the early 1980s, when we both drank at the National Press Club, helping, through its bar takings, to establish the club as a national institution. Paul was usually there together

1 Paul Dibb, Siberia and the Pacific: A Study in Economic Development and Trade Prospects (New York: Praeger, 1972).

2 Jeffrey T. Richelson, The Wizards of Langley: Inside the CIA's Directorate of Science and Technology (Boulder, Colorado: Westview Press, 2001), p. 109. 
with his great mate Jim Clapham, talking about cars, current political events (for Jim was an avid consumer of the daily media), car tyres, car engines, rpms, and other things about cars. He was also often joined by another good friend, Don Marshall, or 'the sheriff', then the head of the Australian Security Intelligence Organisation's (ASIO) Canberra regional office. Paul later brought Marshall over to Defence to head the Defence Security Branch and, in particular, to quietly abolish its malfunctioning Office of Special Clearances and Records (OSCAR).

In those days, Lev Sergeyevich Koshlyakov, the KGB resident in Canberra also used to drink at the Press Club with Paul, Clapham and Marshall, intermingling with journalists such as Brian Toohey, Bill Pinwill and Mungo MacCallum - every one of them more or less drunk as the evenings wore on. It was a fascinating scene and, while I never knew how much of it had been scripted by Paul and Marshall, I'm sure a lot of it had.

It was at the Press Club, later in the 1980s, that I first met Rhondda Nicholas; she and Paul had started to get to know each other when Rhondda was head of the Papua New Guinea and South Pacific Policy Section in Defence. Incidentally, they later wrote a book together, Restructuring the Papua New Guinea Defence Force (1996). ${ }^{3}$

Paul came back to ANU as a senior research fellow in the Department of International Relations in 1981, and then transferred to Strategic and Defence Studies Centre (SDSC) in 1984, becoming its deputy head. This was when he wrote his prescient study The Soviet Union: The Incomplete Superpower, first published in $1986,{ }^{4}$ which he regards as his single most important work.

In February 1985 he took leave from ANU to serve as a ministerial consultant to Kim Beazley, and completed his Review of Australia's Defence Capabilities, commonly known as the Dibb Review, in

3 Paul Dibb \& Rhondda Nicholas, Restructuring the Papua New Guinea Defence Force: Strategic Analysis and Force Structure Principles for a Small State, report to the Minister for Defence of Papua New Guinea (Canberra: Strategic and Defence Studies Centre, 1996).

4 Paul Dibb, The Soviet Union: The Incomplete Superpower (London: International Institute for Strategic Studies and Macmillan, 1986). 
June $1986 .{ }^{5} \mathrm{He}$ then returned to Defence, initially as Director of JIO (1986-88) and then as the Deputy Secretary (Strategy and Intelligence) from 1988 to 1991 .

With regard to the strategy side of his portfolio, Paul's primary responsibility was to exercise oversight and direction of implementation of the 1987 White Paper The Defence of Australia with respect to forcestructure acquisitions and operational concepts for controlling the sea-air gap and thus effecting the defence of Australia on a self-reliant basis. One of the responsibilities of the Deputy Secretary (Strategy and Intelligence) was to chair the Force Structure Committee, which approved new capital acquisitions. Paul regards this as having been his most powerful job, rather than either the strategic policy or intelligence dimensions. It was not easy to persuade the Services of the necessity of according new capability proposals with strategic guidance. The biggest fight was with the Navy, which wanted larger and more capable frigates than the ANZAC-class that Paul proposed. Paul won that fight, although he lost the argument about the size of the guns they would carry (five-inches rather than his recommended three-inches). Paul believes that the most important force-structure project he recommended to government was the Jindalee over-thehorizon radar system, about which the Royal Australian Air Force (RAAF) was unenthusiastic and that mired the Defence Science and Technology Organisation (DSTO) in technical matters.

On the intelligence side, he had considerable difficulties with the Defence Signals Directorate (DSD) hierarchy in Melbourne and, in particular, DSD's Director Tim James. In 1990, Paul, and thence the Secretary, Tony Ayres, learned that DSD maintained some SIGINT 'compartments' from which they and the Minister for Defence were excluded. As a result, they were persuaded that 'DSD's primary allegiance was to the UKUSA SIGINT community rather than Australia's policy priorities'. Ayres and Paul resolved that the DSD HQ should be moved to Canberra and, together with Allan Hawke, who was then the Deputy Director of DSD, they planned the construction of Building M in the Russell Hill complex in Canberra to which DSD's activities and records would be relocated. The move was strongly resisted by James, who argued that 'no-one would come from Melbourne', but who was

5 Paul Dibb, Review of Australia's Defence Capabilities, report to the Minister for Defence (Canberra: Australian Government Publishing Service, 1986). 
really intent on preserving his operational autonomy. This is when Paul worked most closely with Hawke. (Hawke succeeded Dibb as Deputy Secretary (Strategy and Intelligence) in 1991.)

Paul also had important roles in the 'modernisation' of New Zealand's SIGINT capabilities. In the late 1970s, when he was Deputy Director of JIO (Civilian), he was involved in assisting the development of the NZ Government Communications Security Bureau (GCSB), which was established in 1977. He participated in discussions with GCSB about the establishment of a new SIGINT station at Tangimoana, equipped with a large Pusher-type circularly disposed antenna array (CDAA) for HF interception and direction-finding, which was to operate as part of the UKUSA naval ocean surveillance system. (Similar CDAAs were installed in the mid-1970s at DSD stations at the RAAF Base Pearce, near Perth; Cabarlah near Toowoomba; and Shoal Bay near Darwin.) In 1987-89, as Director of JIO and then Deputy Secretary (Strategy and Intelligence), he was directly involved with GCSB concerning the planning and development of the foreign satellite/communications satellite (FORNSAT/COMSAT) interception station at Waihopai, which has a close operational relationship with the Australian Defence Satellite Communications Station at Kojarena, near Geraldton.

Dibb also served during 1988-91 as the chief Australian interlocutor with the United States with respect to the joint facilities, including with the CIA and the National Reconnaissance Office (NRO) in the case of Pine Gap and the Rhyolite satellites and their successors. (Organisationally, CIA SIGINT and imaging satellites comprised the NRO's Program B). His prime responsibility was to ensure that all activities at Pine Gap were conducted with the 'full knowledge and concurrence' of the Defence Minister, which was to be guaranteed not only by the placement of Australians in all parts of the operations areas at the ground station but also the requirement that Australia approve all changes to the bore-sight of the intercept antennas, and hence the collection targets, of the satellites. He had been 'briefed into' (or 'indoctrinated into') the joint facilities in November 1974, when he became head of the NAS, a process directed by Mathams. One of the first matters with which he was involved was the preparation of draft advice for the Minister, in 1975, regarding a US proposal to target a Rhyolite satellite on the Soviet naval base and communications centre at Berbera, in north-west Somalia, on the Gulf of Aden. (Paul retained all his relevant clearances until 2004, a remarkable 30 years.) On the 
US side, he dealt with Leslie Dirks, who succeeded Carl Duckett as DDS\&T and head of Program B in 1976, and Richard Evans Hineman, who succeeded Dirks in 1982. He knew Milton Corley Wonus, the CIA Station Chief in Canberra in 1975-80. Wonus, who had joined DDS\&T in 1963, later served as Director of the Office of SIGINT Operations in DDS\&T, the office in charge of operating the Pine Gap ground station. ${ }^{6}$

In 1990-91, as shown in photos 7 and 8, Paul was recognised by the NRO for his 'outstanding support of US-Australian space cooperation' and, in particular, for his support of its Program B during his period as Deputy Secretary (Strategy and Intelligence) in 1988-91.

Paul is intensely loyal towards his adopted country. He is a nationalist and he loves Australia. As the geographic heart of his concepts for Australian strategic policy and defence planning, he found it natural to provide unequivocal representation of Australia's interests in the UK-USA intelligence cooperation councils. He was, despite his origins, in no sense beholden to his British counterparts. As Hawke relates in Chapter 1, he was quick to note during his last official visit to London in 1991 that he represented the Australian Government, and certainly not the British establishment, which had excluded him from its ranks.

I began sounding Paul out about possible interest in heading SDSC in mid-1989. I was frustrated with administration, which was undoubtedly less arduous than in more recent times, for which I was clearly unsuited. Somewhat to my surprise, for this involved a major career change and a commitment to academia rather than a temporary stay, Paul warmed to the idea. In July 1989 at the National Defence Seminar at Canungra, which was sponsored by Kim Beazley as Minister for Defence and General Peter Gration as Chief of the Defence Force $(\mathrm{CDF}), \mathrm{I}$ asked the Minister what he thought about the proposition, and he gave it his blessing.

The references that the university solicited for Paul's appointment to a special professorship at ANU and headship of the centre were exceptional in their judgements. Sir Arthur Tange, commenting on Paul's 'rare versatility', said that as Deputy Director (Civilian) and later Director of JIO and Deputy Secretary (Strategy and Intelligence) he had 'done much to redirect the activities of the intelligence community

6 Richelson, The Wizards of Langley (2001), pp. 295-97. 
to matters more closely related to the practical defence interests of the country'; and asserted that on defence policy issues 'there is none inside or outside the Defence Community better equipped at present to understand the issues in contention and the policy choices', and that Paul had exhibited remarkable 'courage in arguing with the Services about their own business [i.e. weapons acquisition]'. He also, I might add, could not resist using his reference for Paul to make some caustic remarks about myself, saying that I had evinced 'some imbalance in the choice of subjects of study', including the joint facilities 'which successive American and Australian Governments have deemed it a national interest' to keep secret, and expressing relief that I would no longer be heading the Centre. Gareth Evans said that 'Dr Dibb's intellectual capacities ... are among the most outstanding of the public servants I have encountered in this area of Government'. Gration commented on Paul's 'intellectual rigour', and noted that he had 'a unique blend of academic experience and real life strategic policy making, where theoretically attractive concepts have to be tempered with practical realities' and that he had 'a mature understanding of the capabilities, aspirations and limitations of the armed forces as instruments of national policy'. Admiral Ron Hays, who had just retired from the post of US Commander in Chief, Pacific, said he was 'by American standards, a national asset'. Michael MccGwire of the Brookings Institution in Washington said that he had 'earned a first class [international] reputation'. By this time, 1991, Paul had written two books, two major government reports, and more than 30 chapters and articles in scholarly books and journals.

Paul officially became head of the SDSC in October 1991, and went on to be its longest-serving head, passing Bob O'Neill's tenure in 1971-82 by a few months. He officially retired as head in February 2003, but went upstairs to chair the SDSC Advisory Board. The Centre took some hard knocks in the 1990s, as we suffered from the vicissitudes of dependence on funding from external sources and, more painfully felt, cuts in the Centre's university funding and a shift in school priorities, which decimated most of our work on Australian defence. It tested all of Paul's skills in academic diplomacy. But it did not diminish his productivity. He published an Adelphi Paper for the International Institute for Strategic Studies (IISS) on the emerging balance of power in Asia in 1995, and path-breaking articles on the revolution in military affairs in Asia, the US alliance, and Australian 
defence policy. He has also done substantial work, including studies of various sectors of Australian defence industry, that is not for publication.

Essential personal characteristics emerge from a review of Paul's career, apart from his high motivation and propensity for hard work. First, he places a high value on mateship, reinforced by regular eating and drinking sessions at restaurants in inner Canberra or at his farm at Robertson, with his closest mates (who include both current and former senior figures in the intelligence community). Second, he is proud to be an Australian and has, perhaps, even been thrilled that he could represent Australia's intelligence and defence interests so well. There are undoubtedly close connections between some aspects of his strong desire to preserve a high degree of personal privacy and his carriage of Australia's top intelligence secrets.

Third, like the Berlin-Ayson hedgehog, he can be very protective, even possessive, about his core ideas. As Ayson says, Paul can be 'intimidating to those unfortunate enough to get in his way'. Indeed, he can be blunt, even combative. I, for example, was the cause of his great displeasure when I openly disagreed with a couple of basic themes in the Dibb Review, and suggested that the policy of 'denial' needed to be complemented by capabilities for counteroffensive operations. I also stated that the review accorded insufficient attention to Australia's long-range strike requirements and undervalued the F-111s; I felt that the assumptions about 'warning time' were too sanguine. ${ }^{7}$ I sometimes shudder when he characterises some of our academic colleagues, or the officials in a certain government department concerned with foreign affairs, or our allies across the sea to the south-east (notwithstanding his appreciation of the very close and mutually fruitful cooperation between DSD and GCSB in the SIGINT field).

How are these key characteristics of his personality - the mateship, the bluntness, the outspokenness, the combativeness - best explained? I think that there is still a fair dose of his upbringing in the Yorkshire coalmining villages in him.

7 Desmond Ball, 'Notes on Paul Dibb's Review of Australia's Defence Capabilities', notes prepared for an address at the Chief of the Defence Force's Exercise, Australian Defence Force Academy, Reference Paper No. 143, Strategic and Defence Studies Centre, The Australian National University, Canberra, 26-27 August 1986. 
This text is taken from Geography, Power, Strategy and Defence Policy: Essays in Honour of Paul Dibb, edited by Desmond Ball and Sheryn Lee, published 2016 by ANU Press, The Australian National University,

Canberra, Australia. 